\title{
Pemenuhan Pola Makan Gizi Seimbang Dalam Penanganan Stunting Pada Balita Di Wilayah Puskesmas Kecamatan Rawalumbu Bekasi
}

\author{
Rotua Suriany Simamora, Puri Kresnawati \\ Sekolah Tinggi Ilmu Kesehatan Medistra Indonesia \\ Email : yanisimamora12@gmail.com
}

\begin{abstract}
Abstrak
Stunting (pendek) berdasarkan umur adalah tinggi badan yang berada di bawah minus dua standar deviasi (<-2SD) berdasarkan tabel status gizi WHO child growth standard. Stunting dapat menjadi ancaman utama terhadap kualitas manusia Indonesia dan juga ancaman terhadap kemampuan daya saing bangsa. Hal ini dapat terjadi karena anak stunted bukan hanya terganggu pertumbuhan fisiknya saja, melainkan juga terganggu perkembangan otaknya yang sangat mempengaruhi kemampuan dan prestasi di sekolah, produktivitas dan kreativitas di usia produktif. Asupan gizi seimbang dari makanan memegang peranan penting dalam proses pertumbuhan anak. Penerapan pola makan dengan gizi seimbang menekankan pola konsumsi pangan dalam jenis dan jumlah prinsip keanekaragaman pangan untuk mencegah masalah gizi. Komponen yang harus dipenuhi dalam penerapan pola makan gizi seimbang mencakup cukup secara kuantitas, kualitas, mengandung berbagai zat gizi dalam kehidupan sehari-hari serta dapat menyimpan zat gizi untuk mencukupi kebutuhan tubuh. Penelitian ini adalah penelitian epidemiologi analitik observasional menggunakan desain cross sectional. Populasi dalam penelitian ini 200 responden dimana pengambilan sampel menggunakan quota sampling. Selanjutnya dilakukan analisis bivariate menggunakan Chi Square. Hasil penelitian menunjukkan bahwa pemenuhan pola makan gizi seimbang berhubungan dengan penanganan stunting pada balita dengan $p$ value sebesar 0,035 dan Odds Ratio 2.304.
\end{abstract}

Kata Kunci : Gizi Seimbang, Stunting, Balita

\begin{abstract}
Stunting (short) by age is a height that is below minus two standard deviations (<-2SD) based on the WHO child growth standard nutritional status table. Stunting can be a major threat to the quality of Indonesian people and also a threat to the nation's competitiveness. This can occur because stunted children are not only disturbed by their physical growth, but also their brain development which greatly affects their ability and achievement at school, productivity and creativity at productive age. A balanced nutritional intake from food plays an important role in the child's growth process. The application of a diet with a balanced nutrition emphasizes the pattern of food consumption in the type and number of principles of food diversity to prevent nutritional problems. The components that must be fulfilled in the application of a balanced nutritional diet include sufficient quantity, quality, contain various nutrients in daily life and can store nutrients to meet the needs of the body. This study was an observational analytic epidemiological study using a cross sectional design. The population in this study were 200 respondents where the sampling used quota sampling. Furthermore, bivariate analysis was carried out using Chi-Square. The results showed that the fulfillment of a balanced nutritional diet was related to the handling of stunting in children under five with a $p$ value of 0.035 and an Odds Ratio of 2.304 .
\end{abstract}

http://ejournal.urindo.ac.id/index.php/kesehatan

Article History :

Sumbitted 03 Juni 2021, Accepted 29 Juni 2021, Published 30 Juni 2021 


\section{Jurnal Bidang IImu Kesehatan}

Keyword: Balanced Nutrition, Stunting, under five children

\section{PENDAHULUAN}

Masalah stunting merupakan bukan hanya masalah yang secara nasional melainkan permasalahan global khususnya di negaranegara miskin dan berkembang. Pada tahun 2017 terdapat 22,2\% atau sekitar 150,8 juta balita di dunia mengalami stunting dimana setengah balita stunting di dunia berasal dari Asia (55\%) sedangkan lebih dari sepertiganya (39\%) tinggal di Afrika. Data prevalensi balita stunting yang dikumpulkan World Health Organization (WHO), Indonesia termasuk ke dalam negara ketiga dengan prevalensi tertinggi di regional Asia Tenggara/South-East Asia Regional (SEAR). Rata-rata prevalensi balita stunting di Indonesia tahun 2005-2017 adalah 36,4\% (Kementerian Kesehatan RI, 2018).

Stunting dapat menjadi ancaman utama terhadap kualitas manusia Indonesia dan juga ancaman terhadap kemampuan daya saing bangsa. Hal ini dapat terjadi karena anak stunted bukan hanya terganggu pertumbuhan fisiknya saja, melainkan juga terganggu perkembangan otaknya yang sangat mempengaruhi kemampuan dan prestasi di sekolah, produktivitas dan kreativitas di usia produktif. Anak yang menderita stunting akan lebih rentan terhadap penyakit dan ketika dewasa berisiko untuk mengidap penyakit degeneratif. Kasus stunting pada anak dapat dijadikan sebagai indikator rendahnya kualitas sumber daya manusia suatu negara. Kedaan stunting dapat menyebabkan buruknya kemampuan kognitif, rendahnya produktivitas serta meningkatnya risiko penyakit mengakibatkan kerugian jangka panjang bagi ekonomi Indonesia (Setiawan, Machmud, \& Masrul, 2018).

Studi kualitatif melalui focus group discussion menunjukkan bahwa para ibu balita tidak terlalu khawatir dengan kondisi 'stunting'. Anak yang pendek dan tidak tinggi tidak terlalu mereka khawatirkan karena yang penting anak sehat, bisa bermain dan tidak rewel. Dikatakan pula bahwa lebih pendek dari teman seusianya juga tidak terlalu dipermasalahkan karena orang tuanya juga pendek (Margawati \& Astuti, 2018). Penelitian lain menunjukkan bahwa konsumsi balita berada dalam kategori kurang energi $(55,9 \%)$, protein $(52,6 \%)$ dan kalsium $(52,0 \%)$ dan secara statistik bermakna dengan nilai OR sebesar 4,53;5,34;3,93. Asupan energi, protein, dan kalsium yang rendah disebabkan oleh terbatasnya variasi makanan dan jumlah frekuensi makan yang hanya dua kali sehari berkaitan dengan rendahnya pendidikan orangtua balita (Nabuasa, Juffrie, \& Huriyati, 
2016). Penelitian lain juga menunjukkan bahwa pola asuh merupakan faktor resiko kejadian stunting dengan nilai Odds Ratio sebesar 8,07. Hal ini menunjukkan bahwa balita dengan pola asuh makan kurang memiliki peluang 8 kali lebih besar untuk mengalami stunting, jika dibandingkan dengan balita dengan pola asuh makan baik (Widyaningsih \& Anantanyu, 2018)

Pola makan yang baik belum tentu makanannya terkandung asupan gizi yang benar. Banyak balita yang memiliki pola makan baik tapi tidak memenuhi jumlah dan komposisi zat gizi yang memenuhi syarat gizi seimbang. Asupan gizi seimbang dari makanan memegang peranan penting dalam proses pertumbuhan anak (Mentari \& Agus, 2018). Pola makan menjadi bahian terpenting dalam mengatasi masalah stunting (Kementerian Kesehatan RI, 2018). Penerapan pola makan dengan gizi seimbang menekankan pola konsumsi pangan dalam jenis, jumlah dan prinsip keanekaragaman pangan untuk mencegah masalah gizi. Komponen yang harus dipenuhi dalam penerapan pola makan gizi seimbang mencakup cukup secara kuantitas, kualitas, mengandung berbagai zat gizi (energi, protein, vitamin dan mineral), serta dapat menyimpan zat gizi untuk mencukupi kebutuhan tubuh(Izwardi, 2016). Tingginya prevalensi stunting dan masih rendahnya pemahaman masyarakat dan perilaku tentang pentingnya penerapan pola makan dengan gizi seimbang dalam mencegah stunting menjadi pertimbangan perlunya dilakukan penelitian.

\section{METODE}

Desain penelitian yang digunakan dalam penelitian ini adalah menggunakan observational analitik dengan rancangan penelitian Cross Sectional. Cross Sectional adalah desain penelitian analitik yang bertujuan untuk mengetahui hubungan antar variabel dimana variabel independen dan variabel dependen di identifikasi pada satu waktu (Dharma, 2017). Populasi penelitian ini adalah ibu yang memiliki balita usia 25-60 bulan sebanyak 200 balita dengan teknik quota sampling yang diperoleh dari 10 Posyandu yang berada di bawah wilayah binaan Puskesmas Rawalumbu Bekasi. Pengumpulan data dilakukan dengan menggunakan kuesioner Food Frequency Questionnaires (FFQ) untuk mengukur asupan makanan dan kuesioner yang dibuat oleh peneliti untuk mengukur pencegahan stunting pada balita. Selain itu data yang digunakan dalam penelitian ini mencakup karakteristik orangtua balita (usia, paritas, pendidikan, pendapatan keluarga).

Analisa data dilakukan dengan menggunakan analisis univariate dan bivariate dimana data disajikan dalam bentuk tabel. 


\section{HASIL DAN PEMBAHASAN}

Responden dalam penelitian ini terdiri dari 200 orang yang memenuhi kriteria inklusi.

Tabel 1. Gambaran Distribusi Karakteristik Responden

\begin{tabular}{lll}
\hline $\begin{array}{l}\text { Karakteristik } \\
\text { Responden }\end{array}$ & \multicolumn{1}{c}{ Kategori } & Frekuensi \\
\hline Tingkat & $\begin{array}{l}\text { Tidak } \\
\text { sekolah }\end{array}$ & $8(4 \%)$ \\
Pendidikan & SD & $10(5 \%)$ \\
& SMP & $39(19,5 \%)$ \\
& SMA & $88(44 \%)$ \\
& PT & $55(27,5 \%)$ \\
\hline Sosial & Total & 200 \\
Ekonomi & $>$ UMK & $122(61 \%)$ \\
\hline & Total & 200 \\
\hline Umur & $<20$ & $109(54,5 \%)$ \\
Ibu & $20-30$ & $61(30,5 \%)$ \\
& $>31$ & $30(15 \%)$ \\
\hline Paritas & Primipara & $70(35 \%)$ \\
& Multipara & $130(65 \%)$ \\
\hline & Total & 200 \\
\hline
\end{tabular}

Tabel 1 menunjukkan bahwa karakteristik responden berdasarkan tingkat pendidikan mayoritas adalah SMA sebesar 39 responden $(19,5 \%)$. Tingkat pengetahuan seseorang dapat mempengaruhi dalam upaya pencegahan stunting, karena semakin tinggi tingkat pendidikan seseorang maka semakin mudah untuk menerima informasi (Smeltzer et al, 2008). Dari data sosial ekonomi mayoritas responden dengan tingkat penghasilan dibawah UMK sebesar 122 responden (61\%). Pendapatan keluarga yang rendah merupakan faktor yang berhubungan dengan kejadian stunting pada balita. Penghasilan keluarga yang kecil akan berpengaruh terhadap keterbatasan dan kesulitan dalam mencukupi kebutuhan seharihari. Pendapatan keluarga yang mencukupi akan menunjang perilaku anggota keluarga untuk mendapatkan pelayanan kesehatan yang lebih memadai. Tingkat sosial ekonomi berkaitan dengan daya beli keluarga. Kemampuan keluarga untuk membeli bahan makanan antara lain bergantung pada besar kecilnya pendapatan keluarga dan harga bahan makanan.

Berdasarkan umur ibu dapat diketahui bahwa sebagian besar umur ibu adalah kurang dari 20 tahun sebanyak 109 responden (54,5\%). Kurangnya kematangan berfikir sangat dipengaruhi oleh umur ibu. Hal ini sering sekali membuat ibu labil sehingga ketika anak mereka rewel mereka kesulitan dalam menghadapinya. Pada ibu hamil dengan usia $<20$ tahun memiliki keadaan fisik yang kurang optimal sehingga sehingga sistem reproduksi belum optimal, peredaran darah menuju serviks dan menuju 
uterus belum belum sempurna sehingga dapat mengganggu proses penyaluran zat gizi dari ibu ke janin. Kondisi ini mengakibatkan kebutuhan asupan energy dan zat gizi janin dalam kandungan tidak tercukupi dan hal tersebut dapat menyebabkan janin memiliki masalah gizi saat dilahirkan (Liita, 2019).

Berdasarkan faktor paritas bahwa sebagian besar responden dengan multipara sebanyak 130 responden (65\%). Jumlah anak yang terlalu banyak selain menyulitkan dalam mengurusnya juga kurang bisa menciptakan suasana tenang di dalam rumah. Lingkungan keluarga yang selalu ribut akan mempengaruhi ketenangan jiwa, dan ini secara langsung akan menurunkan nafsu makan anggota keluarga lain yang terlalu peka terhadap suasana yang kurang mengenakan dan jika pendapatan keluarga hanya pas-pasan sedangkan jumlah anggota keluarga banyak maka pemerataan dan kecukupan makanan di dalam keluarga kurang terjamin, maka keluarga ini bisa disebut keluarga rawan, karena kebutuhan gizinya hampir tidak tercukupi. Hasil penelitian menunjukkan bahwa balita stunting lebih banyak yang memiliki ibu dengan paritas banyak dibandingkan ibu dengan paritas sedikit. Sedangkan pada balita yang tidak stunting lebih banyak memiliki ibu dengan paritas sedikit dibandingkan ibu dengan paritas banyak. Dengan demikian dapat dikatakan bahwa pada balita yang stunting cenderung memiliki ibu dengan paritas banyak, sedangkan pada balita yang tidak stunting cenderung memiliki ibu dengan paritas banyak (Palino dkk, 2017).

Tabel 2 Distribusi Responden Menurut Pemenuhan Gizi Seimbang pada Balita Usia 2460 Bulan

\begin{tabular}{|c|c|c|}
\hline Variabel & Kategori & Frekuensi \\
\hline Pemenuhan Gizi & Tidak Terpenuhi & $57(28,5 \%)$ \\
\hline Seimbang & Terpenuhi & $143(71,5 \%)$ \\
\hline \multicolumn{2}{|c|}{ Total } & 200 \\
\hline $\begin{array}{l}\text { Tabel } 2 \\
\text { pemenuhan gizi } \\
\text { Jumlah responden } \\
\text { sebanyak } 143 \text { oran } \\
\text { terpenuhi sejumlah }\end{array}$ & $\begin{array}{l}\text { menunjukkan ga } \\
\text { imbang pada pada } \\
\text { dengan kategori te } \\
\text { g }(71,5 \%) \text { sedangka } \\
57 \text { orang }(28,5 \%) \text {. }\end{array}$ & $\begin{array}{l}\text { nbaran } \\
\text { balita. } \\
\text { penuhi } \\
\text { tidak }\end{array}$ \\
\hline
\end{tabular}

Pemenuhan gizi seimbang mencakup
konsumsi makanan sehari-hari yang mengandung zat gizi dalam jenis dan jumlah yang sesuai dengan kebutuhan tubuh, dengan memperhatikan prinsip keanekaragaman pangan, aktivitas fisik, perilaku hidup bersih dan memantau berat badan secara teratur dalam rangka mempertahankan berat badan normal untuk mencegah masalah gizi (Kesehatan, 2014). Berdasarkan hasil penelitian bahwa pemenuhan gizi seimbang berdasarkan indikator konsumsi makanan yang tidak terpenuhi terdapat pada konsumsi sayursayuran sebanyak 109 orang (54,5\%) dan terpenuhi sebanyak 91 orang (45,5\%). Konsumsi sayur-sayuran yang mengandung vitamin, mineral dan serat merupakan indikator 
sederhana dalam mewujudkan pemenuhan gizi seimbang. Sedangkan untuk konsumsi karbohidrat, protein, lemak dan buah-buahan telah terpenuhi. Penurunan kualitas konsumsi pangan rumah tangga yang dicirikan oleh keterbatasan membeli pangan sumber protein, vitamin dan mineral akan berakibat pada kekurangan gizi, baik zat gizi makro maupun mikro (Nasikhah, Roudhotun. Margawati, 2012).

Penyebab utama gizi kurang pada balita adalah kemiskinan sehingga akses pangan anak terganggu. Penyebab lain adalah ketidaktahuan orang tua karena kurang pendidikan sehingga pengetahuan gizi rendah dan munculnya perilaku tabu makanan, dimana makanan bergizi ditabukan dan tidak boleh dikonsumsi anak balita. Ketidaktahuan tentang gizi dapat mengakibatkan seseorang salah memilih bahan makanan dan cara penyajiannya. Akan tetapi sebaliknya, ibu dengan pengetahuan gizi baik biasanya mempraktekkan pola makan sehat bagi anak-anaknya agar terpenuhi kebutuhan gizinya (Suryani, 2017).

Adapun faktor yang mempengaruhi pemenuhan gizi seimbang pada balita adalah pendidikan ibu, pekerjaan ibu, pendapatan keluarga, jumlah anak dan pola asuh ibu. Dari factor tersebut faktor yang paling berpengaruh adalah pendapatan keluarga(Putri, Sulastri, \& Lestari, n.d.). Ibu yang berpendidikan tinggi biasanya akan memiliki pekerjaan dimana akan berpengaruh terhadap terbatasnya waktu dalam mengasuh anak sehingga perhatian dalam memberikan asupan makanan pada anak akan berkurang. Hal ini dapat mempengaruhi terhadap pemenuhan gizi dan tumbuh kembang balita. Tingkat sosial ekonomi keluarga berkaitan dengan daya beli keluarga. Kemampuan keluarga untuk membeli bahan makanan juga tergantung pada besar kecilnya pendapatan keluarga, harga bahan makanan serta pengelolaannya. Keterbatasan penghasilan keluarga juga akan turut menentukan mutu makanan balita baik secara kualitas maupun jumlah (Nasikhah, Roudhotun. Margawati, 2012).

Jumlah anggota keluarga juga menjadi salah satu faktor yang berpengaruh terhadap pemenuhan gizi balita di keluarga. Jumlah anggota keluarga yang tidak diimbangi dengan peningkatan pendapatan keluarga akan berdampak terhadap pemenuhan gizi balita (Hapsari, 2010). Pemenuhan gizi seimbang pada balita sangat perlu ditekankan dalam upaya pencegahan kasus balita pendek (stunting). Stunting merupakan kondisi dimana balita memiliki panjang atau tinggi badan yang kurang jika dibandingkan dengan umur (Balita, 2016). Gizi seimbang merupakan makanan yang dikonsumsi oleh individu sehari-hari yang beraneka ragam dan memenuhi 5 kelompok zat gizi dalam jumlah yang cukup, tidak berlebihan, dan tidak 
kekurangan (Balita, 2016). Penerapan empat pilar dalam pemenuhan gizi seimbang pada balita perlu memperhatikan keberagaman makanan, membiasakan perilaku hidup sehat, melakukan aktivitas fisik, mempertahankan dan memantau berat badan normal.

Tabel 3 Distribusi Responden Menurut Penanganan Stunting pada Balita Usia 24-60 Bulan

\begin{tabular}{llc}
\hline \multicolumn{1}{c}{ Variabel } & Kategori & Frekuensi \\
\hline Penanganan & Kurang & $42(21 \%)$ \\
Stunting & Baik & $158(79 \%)$ \\
\hline \multicolumn{2}{c}{ Total } & 200 \\
\hline
\end{tabular}

Tabel 3 menunjukkan gambaran penanganan stunting pada balita bahwa sebagian besar penanganan stunting dengan kategori baik sejumlah 158 orang (79\%) dan penanganan stunting dengan kategori kurang sejumlah 42 orang (21\%).

Penanganan stunting melalui pemenuhan zat gizi yang adekuat, baik gizi makro maupun gizi mikro sangat dibutuhkan untuk menghindari atau memperkecil risiko stunting. Kualitas dan kuantitas MP-ASI yang baik merupakan komponen penting dalam makanan karena mengandung sumber gizi makro dan mikro yang berperan dalam pertumbuhan linear. Pemberian makanan yang tinggi protein, kalsium, vitamin $A$, dan zinc dapat memacu tinggi badan anak Pemberian asupan gizi yang adekuat berpengaruh pada pola pertumbuhan normal sehingga dapat terkejar (catch up) (Mustafa, No, Selatan, \& Komunitas, 2015).

Intervensi gizi spesifik dan Intervensi gizi sensitif merupakan intervensi yang ditujukan kepada anak dalam 1.000 Hari Pertama Kehidupan (HPK) dan berkontribusi pada $30 \%$ penurunan stunting. Kerangka kegiatan intervensi gizi spesifik umumnya dilakukan pada sektor kesehatan. Intervensi ini juga bersifat jangka pendek dimana hasilnya dapat dicatat dalam waktu relatif pendek. Kegiatan yang idealnya dilakukan untuk melaksanakan intervensi gizi spesifik mencakup intervensi gizi spesifik dengan sasaran Ibu Hamil. Intervensi ini meliputi kegiatan memberikan makanan tambahan (PMT) pada ibu hamil untuk mengatasi kekurangan energi dan protein kronis, mengatasi kekurangan zat besi dan asam folat, mengatasi kekurangan iodium, menanggulangi kecacingan pada ibu hamil serta melindungi ibu hamil.

Intervensi gizi spesifik dengan sasaran ibu menyusui dan anak usia 0-6 Bulan dilakukan melalui beberapa kegiatan yang mendorong inisiasi menyusui dini/IMD terutama melalui pemberian ASI jolong/kolostrum serta mendorong pemberian ASI Eksklusif. Sedangkan intervensi gizi spesifik dengan sasaran ibu menyusui dan anak usia 7- 23 bulan meliputi kegiatan untuk mendorong penerusan 
pemberian ASI hingga anak/bayi berusia 23 bulan. Kemudian, setelah bayi berusia diatas 6 bulan didampingi oleh pemberian MP-ASI, menyediakan obat cacing, menyediakan suplemen zink, melakukan fortifikasi zat besi ke dalam makanan, memberikan perlindungan terhadap malaria, memberikan imunisasi lengkap, serta melakukan pencegahan dan pengobatan diare (Saputri \& Tumangger, 2019).

$$
\text { Upaya percepatan perbaikan gizi }
$$
merupakan upaya global, tidak saja untuk Indonesia, melainkan semua negara yang memiliki masalah gizi stunting. Upaya ini diinisiasi oleh World Health Assembly 2012. Adapun target yang telah ditetapkan dalam upaya penurunan prevalensi stunting antara lain: menurunnya prevalensi stunting, wasting dan mencegah terjadinya overweight pada balita, menurunkan prevalensi anemia pada wanita usia subur, menurunkan prevalensi bayi berat lahir rendah (BBLR), meningkatkan cakupan ASI eksklusif. Sebagai negara anggota PBB dengan prevalensi stunting yang tinggi turut berupaya dan berkomitmen dalam upaya percepatan perbaikan gizi 'scaling up nutrition (SUN)' masyarakat (Aryastami, 2017).

Tabel 3 Hubungan Pemenuhan Gizi Seimbang dalam Penanganan Stunting pada Balita Usia 24-60 Bulan

\begin{tabular}{|c|c|c|c|c|c|}
\hline \multirow{3}{*}{$\begin{array}{c}\text { Pemenuban } \\
\text { Gizi } \\
\text { Seimbang }\end{array}$} & \multicolumn{2}{|c|}{$\begin{array}{l}\text { Penanganan } \\
\text { Stunting }\end{array}$} & \multirow[t]{2}{*}{ Total } & \multirow{3}{*}{$\begin{array}{l}\text { OR } \\
(95 \% \\
\text { Cl) }\end{array}$} & \multirow[t]{3}{*}{$\begin{array}{l}\text { P } \\
\text { Value }\end{array}$} \\
\hline & Kurang & Baik & & & \\
\hline & $\mathrm{F}$ & $\mathrm{F}$ & $\mathrm{F}$ & & \\
\hline $\begin{array}{c}\text { Tidak } \\
\text { Terpenuhi }\end{array}$ & $\begin{array}{c}17 \\
(40,5 \%)\end{array}$ & $\begin{array}{c}25 \\
(59,5 \%)\end{array}$ & $\begin{array}{c}42 \\
(100 \%)\end{array}$ & 2.304 & 0.035 \\
\hline Terpenuhi & $\begin{array}{c}36 \\
(22,8 \%) \\
\end{array}$ & $\begin{array}{c}122 \\
(77,2 \%) \\
\end{array}$ & $\begin{array}{c}158 \\
(100 \%)\end{array}$ & & \\
\hline Total & 53 & 147 & 200 & & \\
\hline
\end{tabular}

Tabel 3 menunjukkan pemenuhan gizi seimbang dalam penanganan stunting pada balita di wilayah Puskesmas Bojong Rawalumbu. Dapat diketahui bahwa pemenuhan gizi seimbang yang tidak terpenuhi dengan penanganan kurang sebanyak 17 orang (40.5\%) dan dengan penanganan baik sebanyak 25 orang (59.5\%). Sedangkan pemenuhan gizi seimbang yang terpenuhi dengan penanganan kurang sebanyak 36 orang $(22,8 \%)$ dan dengan penanganan baik sebanyak 122 orang (77.2\%).

Hasil analisa data statistik diperoleh $\mathrm{p}$ value sebesar 0,035 dengan taraf signifikansi 0,05 . Hasil uji hipotesis dari pemenuhan gizi seimbang $(p=0,035)$ berhubungan dengan penanganan stunting pada balita. Pada tabel tersebut juga diketahui Odds Ratio (OR) sebesar 2,304 yang berarti bahwa pemenuhan gizi yang terpenuhi akan berpeluang 2,304 dalam penanganan stunting dengan baik dibandingkan dengan pemenuhan gizi seimbang yang tidak terpenuhi.

Stunting adalah kondisi gagal tumbuh pada anak balita (bayi dibawah lima tahun) 
akibat dari kekurangan gizi kronis sehingga anak terlalu pendek untuk usianya. Kekurangan gizi terjadi sejak bayi dalam kandungan dan pada masa awal setelah bayi lahir akan tetapi, kondisi stunting baru setelah bayi berusia 2 tahun. Balita pendek (stunted) dan sangat pendek (severely stunted) adalah balita dengan panjang badan $(\mathrm{PB} / \mathrm{U})$ atau tinggi badan $(\mathrm{TB} / \mathrm{U})$ menurut umurnya dibandingkan dengan standar baku WHO-MGRS (Multicentre Growth Reference Study) (Kesehatan, 2014).

Gizi juga sangat berperan dalam membantu aktivitas anak karena proses-proses fisiologis di dalam tubuhnya. Proses-proses fisiologis ini dalam menjalankan fungsinya sangat memerlukan zat gizi seperti karbohidrat, protein, dan lemak yang dirombak menjadi Demikian agar tercukupi energinya diperlukan pemasukan zat-zat gizi yang cukup pula ke dalam tubuhnya. Anak yang memiliki gizi yang baik akan memberikan kesempatan lebih besar untuk melakukan aktivitas dengan lingkungannya. Anak yang memiliki keadaan gizi yang kurang akan cenderung terganggu dalam perkembangan personal sosialnya (Musyafirah, 2014)

Hasil penelitian ini menunjukkan bahwa terdapat hubungan antara pemenuhan gizi seimbang dengan penanganan stunting pada balita. Analisa data menggunakan uji Chi Square dengan taraf signifikan sebesar 0,05 diperoleh $p$ value adalah 0,035 yang berarti nilai tersebut lebih kecil dari nilai taraf signifikan $(0,035<$ $0,05)$ yang menunjukkan ada hubungan pemenuhan gizi seimbang dengan penanganan stunting pada balita wilayah Puskesmas Bojong Rawalumbu Bekasi. Hasil analisa data didapatkan hasil bahwa nilai Odds Ratio (OR) sebesar 2,034 yang berartinya pemenuhan gizi seimbang yang terpenuhi berpeluang 2,034 kali untuk memiliki penanganan stunting yang lebih baik dibandingkan pemenuhan gizi yang tidak terpenuhi.

Status stunting di pengaruhi oleh pemenuhan pola pengasuhan kebutuhan dasar pada balita. Semakin baik pola pengasuhan ibu maka akan semakin baik pertumbuhan anak. Pada hasil penelitian ini menujukan bahwa ada hubungan antara pemenuhan kebutuhan asuh ibu terhadap status stunting pada balita usia 1-5 tahun (Supartini Tri, Lilis Lestari, n.d.). Praktek pengasuhan yang tidak baik berhubungan dengan kurangnya pengetahuan masyarakat tentang kesehatan dan gizi sebelum dan pada masa kehamilan. Kondisi kesehatan dan gizi ibu sebelum dan saat kehamilan serta setelah persalinan mempengaruhi pertumbuhan janin dan risiko terjadinya stunting. Janin yang tumbuh dalam kandungan ibu yang mengalami kurang gizi kronis (KEK) akan beradaptasi dengan lingkungannya. Penyesuaian pertumbuhan janin tersebut menyebabkan pertumbuhan yang tidak optimal atau retardasi 
yang dikenal dengan istilah intra uterine growth retardation (IUGR).

Intervensi spesifik adalah tindakan atau kegiatan yang dalam perencanaannya ditujukan khusus untuk kelompok 1000 hari pertama kehidupan (HPK) dan bersifat jangka pendek. Kegiatan ini umumnya dilakukan di kesehatan seperti mengadakan imunisasi lengkap, pemberian PMT ibu hamil dan balita, monitoring pertumbuhan balita di Posyandu, suplementasi tablet besi-folat pada ibu hamil, promosi ASI eksklusif, MP-ASI, dan sebagainya. Sedangkan intervensi adalah berbagai kegiatan pembangunan di luar kesehatan yang ditujukan pada masyarakat umum. Beberapa kegiatan tersebut meliputi penyediaan air bersih, sarana sanitasi yang baik, penanggulangan kemiskinan, ketahanan pangan dan gizi, fortifikasi pangan, KIE gizi dan kesehatan, kesetaraan gender, dan lain-lain (Hardani \& Zuraida, 20193).

Pemenuhan gizi seimbang yang baik akan dapat menurunkan kejadian stunting pada balita usia 36-59 bulan. (Widiastuti et al., 2018). Asupan zat gizi yang tidak seimbang adalah salah satu faktor yang berpengaruh langsung terhadap stunting. Dengan pemenuhan kebutuhan gizi anak dan pembiasaan pola hidup bersih sehat, diharapkan akan mencegah stunting bagi anak-anak (Pabean, Dringu, \& Probolinggo, 2019).

\section{SIMPULAN}

Berdasarkan penelitian yang sudah dilakukan pada 200 responden dapat diketahui bahwa mayoritas tingkat pemenuhan gizi seimbang pada balita adalah terpenuhi sebesar $143(71,5 \%)$ dan penanganan stunting sebagian besar baik yaitu baik sebesar 158 responden (79\%). Analisa data menggunakan uji Chi Square dengan taraf signifikan sebesar 0,05 diperoleh $p$ value adalah 0,035 yang berarti nilai tersebut lebih kecil dari nilai taraf signifikan $(0,035<$ $0,05)$ yang menunjukkan ada hubungan pemenuhan gizi seimbang dengan penanganan stunting pada balita wilayah Puskesmas Bojong Rawalumbu Bekasi. Hasil analisa data statistik diperoleh $p$ value sebesar 0,035 dengan taraf signifikansi 0,05. Pada tabel tersebut juga diketahui Odds Ratio (OR) sebesar 2,304 yang berarti bahwa pemenuhan gizi yang terpenuhi akan berpeluang 2,304 dalam penanganan stunting dengan baik dibandingkan dengan pemenuhan gizi seimbang yang tidak terpenuhi.

\section{DAFTAR PUSTAKA}

Aryastami, N. K. (2017). Kajian Kebijakan dan Penanggulangan Masalah Gizi Stunting di Indonesia. Buletin Penelitian Kesehatan, 233-240.

Dharma, K. K. (2017). Metodologi Penelitian Keperawatan (Pedoman Melaksanakan Dan Menerapkan Hasil Penelitian). Jakarta 
Timur: CV. Trans Info Media.

Hapsari, D. (2010). Peran Keluarga Terhadap Pemenuhan Kebutuhan Konsumsi Keluarga Guru Sekolah Dasar Kabupaten Jember 2010. Universitas Jember.

Hardani, M., \& Zuraida, R. (20193). Penatalaksanaan Gizi Buruk dan Stunting pada Balita Usia 14 Bulan dengan Pendekatan Kedokteran Keluarga Management Of Underweight and Stunting in 14 Months Children with Family Medicine Approach. Medula, 9, 565-575.

Izwardi, I. D. (2016). Inilah Perbedaan 4 Sehat 5 Sempurna Dengan Gizi Seimbang. Kementrian Kesehatan Republik Indonesia, $1-2$.

Kementerian Kesehatan RI. (2018). Pusdatin : buletin stunting. Kementerian Kesehatan $R I, 1,2$.

Kementerian Kesehatan RI. (2014) Peraturan Menteri Kesehatan Republik Indonesia Nomor 41 Tahun 2014 Tentang Pedoman Gizi Seimbang.

Margawati, A., \& Astuti, A. M. (2018). Pengetahuan ibu, pola makan dan status gizi pada anak stunting usia 1-5 tahun di Kelurahan Bangetayu, Kecamatan Genuk, Semarang. Jurnal Gizi Indonesia, 6(2), 82. https://doi.org/10.14710/jgi.6.2.82-89
Mentari, S., \& Agus, H. (2018). Faktor-faktor yang Berhubungan dengan Status Stunting Anak Usia 24-59 Jurusan Gizi Poltekkes Kemenkes Pontianak Indonesia. Pontianak Nutrition Journal (PNJ), 1(1), 1-5.

Mustafa, J., No, S., Selatan, T., \& Komunitas, J. K. (2015). Permasalahan Anak Pendek ( Stunting ) dan Intervensi untuk Mencegah Terjadinya Stunting ( Suatu Kajian Kepustakaan ) Stunting Problems and Interventions to Prevent Stunting ( A Literature Review ). 2(5).

Musyafirah, M. (2014). Related Factors Of Social Personal Task Achievement of Preschool Children. 1(1), 31-37.

Nabuasa, C. D., Juffrie, M., \& Huriymusyafirahati, E. (2016). Riwayat pola asuh, pola makan, asupan zat gizi berhubungan dengan stunting pada anak 24-59 bulan di Biboki Utara, Timor Tengah Utara, Nusa Tenggara Timur. Jurnal Gizi Dan Dietetik Indonesia (Indonesian Journal of Nutrition and Dietetics), 1(3), 151. https://doi.org/10.21927/ijnd.2013.1(3).1 51-163

Nasikhah, Roudhotun. Margawati, A. (2012). Online di : http://ejournals1.undip.ac.id/index.php/jnc Prevalensi stunting di Jawa Tengah kejadian tertinggi di Kecamatan Semarang Timur. Journal of Nutrition College, 1(1), 176-184. Retrieved 
Jurnal Bidang Ilmu Kesehatan

from http://ejournal-

s1.undip.ac.id/index.php/jnc\%OAFAKTOR

Pabean, D., Dringu, K., \& Probolinggo, K. (2019).

Upaya Pencegahan Stunting Melalui

Pemberian Makanan Tambahan dan

Penerapan Pola Hidup Bersih dan Sehat di

PAUD Tunasmulya Desa Pabean Kecamatan Dringu Kabupaten

Probolinggo. Jurnal Abdi Panca Marga, 1(1), 25-29.

Putri, R. F., Sulastri, D., \& Lestari, Y. (n.d.). Artikel Penelitian Faktor-Faktor yang Berhubungan dengan Status Gizi Anak Balita di Wilayah Kerja Puskesmas Nanggalo Padang. 4(1), 254-261.

Saputri, R. A., \& Tumangger, J. (2019). Hulu Hilir Penanganan Stunting di Indonesia. Jurnal of Political, 1(1), 1-9.

Setiawan, E., Machmud, R., \& Masrul. (2018). Ein Glossar für die NetAcademy. Jurnal Kesehatan Andalas, 7(2), 275-284.
Supartini Tri, Lilis Lestari, W. (n.d.). Hubungan Pemenuhan Kebutuhan Asuh Ibu Terhadap Status Stunting Pada Balita Usia 1-5 Tahun di Puskesmas X Kabupaten Kubu Raya. 2.

Suryani, L. (2017). Faktor Yang Memepengaruhi Status Gizi Balita di Wilayah Kerja Puskesmas Payung Sekaki Pekanbaru. 1(2), 47-53.

Widiastuti, R. N., Redaksi, P., Meiningsih, S., Redaksi, W. P., Nugraha, D. A., Pelaksana, R., ... Hapsari, O. P. (2018). Hubungan Pola Pemberian Makanan Dengan Stunting Pada Balita Usia 36-59 Bulan di Desa Mulo dan Wunung di Wilayah Kerja Puskesmas Wonosari I.

Widyaningsih, N. N., \& Anantanyu, S. (2018). Jurnal Gizi Indonesia Keragaman pangan, pola asuh makan dan kejadian stunting pada balita usia 24-59 bulan. Jurnal Gizi Indonesia, 7(1), 22-29. 